\title{
“Non, je parle pas français [...] I see subtitles under people when they speak": Language Choice and Identity Construction in Contemporary Canadian Popular Culture
}

\begin{abstract}
Habits of language use and attitudes towards it play a major role in determining cultural and national identities. In the Canadian context of an officially bilingual country, language is one of the fastest and easiest ways of constructing different linguacultural identities. Likewise, bilingualism itself becomes part of the national narrative, contributing to the creation of a bilingual national identity. This article demonstrates how language choice is used to construct identities in contemporary Canadian popular culture, using three examples: the songs 1916 by Gérard Jean and À Moncton by Marie-Jo Thério, and the bilingual movie Bon Cop Bad Cop, directed by Eric Canuel. A close analysis of English/French language use in these examples illustrates different strategies of identity construction, ranging from a parallel depiction of identities that are recognized as autonomous yet inextricably interconnected parts of a whole; to an equal partnership where language does not divide but unites to create a joint bilingual identity; to a mixed and hybrid identity. The three works of popular culture illustrate how the challenges of an officially bilingual country can be met with regard to society at large, as well as on an individual level in interpersonal interactions.
\end{abstract}

Keywords: biculturalism, bilingualism, Canada, Chiac, code-switching, identity construction, mixed languages, popular culture, translanguaging

\section{Introduction}

The construction of identity is often inseparably intertwined with language. Habits of language use and attitudes towards it play a major role in determining cultural and national identity. In the Canadian context of an officially bilingual and multicultural country, language may even be considered the fastest and easiest way of constructing and asserting cultural heritage, although other cultural traditions and customs can certainly be equally useful. Outside Quebec, Francophone communities are usually in a minority situation where choice of language seems to be an easy and effective way of displaying cultural affiliation and Franco-Canadian identity. Likewise, French and the preservation of the French language are essen-

2 Open Access. (C) 2021 Marie-Louise Brunner, published by De Gruyter. (c) BY-NC-ND This work is licensed under the Creative Commons Attribution-NonCommercial-NoDerivatives 4.0 International License. 
tial aspects of Franco-Québécois life, making an assertive use of English in this context particularly noticeable.

This article discusses the construction of Canadian identities through language choice in the context of Canadian bilingualism in contemporary Canadian popular culture, using an intermedial approach. A close analysis of language use in two songs (1916 by Gérard Jean and $A$ Moncton by Marie-Jo Thério) and a film (Bon Cop Bad Cop, directed by Eric Canuel) illustrates how different identities are negotiated and how the relationship between English and French contributes to creating, presenting, and emphasizing identities in the Canadian bilingual context.

\section{Identities in the Canadian context}

According to anti-essentialist approaches, identity is socially negotiated and constructed. Based on social expectations, our identity - or rather identities - can be seen as roles we play which are constantly negotiated and renegotiated according to context. As Hall (1992, 277) observes, “the subject assumes different identities at different times," which are constructed based on personal, interpersonal, and situational factors (see Swann and Bosson 2008, 460). This means that identities are "discursively constructed through language" (Baker 2015, 375) in their respective settings.

In this context, we should consider Barker's $(2000,173)$ observation that "meaning is generated through relations of difference" and Edwards's claim (following Barth 1969) that "what is essential for the continuation of a sense of groupness is the continuation of a sense of distinctiveness that allows perceptual boundaries to be maintained" (Edwards 2009, 9). This suggests that meaning is generated in opposition to other meanings, just as identities, and in particular cultural group identities, are created in opposition to other identities. We can thus argue not only that language is, as a means of meaning-making, an important aspect of identity creation, but also that the opposition of different languages contributes to the creation of different cultural identities. Francophone identity can thus be constructed in opposition to Anglophone identity in the context of Canadian bilingualism and biculturalism, and vice versa. On a national level, however, the official Canadian bilingualism policies contribute essentially to the creation of a "narrative of the nation" (Barker 2000, 198) as being bilingual, transcending the Anglophone-Francophone opposition. As a result of these policies, bilingualism is an essential part of the Canadian national self-image as a multiethnic bilingual “imagined community” (see Anderson 1983). This is in line with Barker's (2000, 
197) observation that "nations are not simply political formations but systems of cultural representation through which national identity is continually reproduced as discursive action," which means that the effects of bilingual policies on everyday Canadian cultural practices lead to the continued construction of a bilingual nation.

\section{Language choice and identity construction}

Where identity construction through language choice is concerned, various language contact phenomena need to be considered, ranging from code-switching to translanguaging practices to mixed languages.

Code-switching is a "phenomenon of language contact" (Auer and Eastman 2010, 85; emphasis in original), that is, an interplay of different "codes," in this case different languages. It "symbolizes identities beyond the linguistic fact" (Auer 2005, 404), that is, beyond the mere fact of being able to use more than one language. Instead, it is used to demonstrate social, ethnic, and/or cultural group memberships (see e.g. Brunner and Diemer 2018). A phenomenon that goes beyond code-switching, while including it, is translanguaging (García 2009, 45), which García and Wei $(2014,5)$ see "as a way to capture the fluid language practices of bilinguals without giving up the social construction of language and bilingualism under which speakers operate." The concept depicts language use with interlaced and permeable boundaries. Following the constructivist approach to cultural identity (see section 2 above), it can be argued that the use of both code-switching and translanguaging can be construed as part of an identity-building process. Ochs $(1993,288)$ points out that "linguistic constructions [...] are crucial indicators of social identity," while Cashman $(2005,313)$ states that "language preference" can be interpreted "as a membership categorization device," further emphasizing the important role that language choice plays in the construction of identity.

In the context of Canadian bilingualism, additional considerations have to be taken into account. Bakker and Matras (2013) observe that, if multiple languages are available, "a new mode of communication drawing on these multiple repertoires may emerge" (1), using this "multilingual repertoire to create a new speech variety" (4). In this case, the choice of one language over the other can become blurred as languages intertwine to create something new. This is often "connected to processes of identity shift, identity formation" (4), and to "flagging group solidarity" (9), suggesting that not only language choice, but also mixing languages and creating new varieties, can contribute to identity negotiation processes. 


\section{Identity construction in contemporary Canadian popular culture}

In this article, I trace the cultural phenomenon of identity construction through language choice across different genres and media of popular culture (song and film), following Wolf's $(1999,36)$ broad definition of intermediality as "any phenomenon involving more than one medium," including "general cultural [...] trends which disregard or transcend medial boundaries.”

Three examples of Canadian popular culture from three provinces, all with different policies regarding the relationship between French and English, are analysed in this section to illustrate different approaches to linguistic and cultural identities in the bilingual Canadian context. While Canada as a whole recognizes both English and French as official languages, and bilingualism is a basic principle guaranteed by the Constitution (Office of the Commissioner of Official Languages 2015), the situation varies considerably between the different provinces, and only $17 \%$ of the population are actually bilingual (Henripin 2014). The three works to be analysed here originate in the provinces of Manitoba, New Brunswick, and Quebec, which are the only provinces that are "covered by supplementary constitutional protection" (Vaillancourt et al. 2012, vi) guaranteeing minority language rights and putting additional emphasis on bilingualism. Even though speakers from these provinces are certainly not all fluent in both languages, their recognition and understanding of the concept of a bilingual society can be expected to be more elaborate than in other provinces.

(1) 1916 is a song from 1986 by Gérard “Ziz” Jean, who, even though originally from Thunder Bay, Ontario, has long been adopted by the Francophone community in Manitoba as "l'enfant chéri de la francophonie manitobaine" [the dear child of the Manitoban Francophonie] because he has composed a wide range of songs that are part of the standard repertoire of many Franco-Manitoban choirs (Boulianne, Dugas, and Jean 2010). ${ }^{1}$ The song reflects the complex and unique history of language policy in the provincial context. Even though Manitoba was declared bilingual in 1870, this was revoked for legal contexts in 1890 and then for educational contexts in 1916 (cf. the song's title), when English was adopted as the only official language of education. These decisions were only repealed in 1985 by a Supreme Court judgment which was reinforced in 2016 (Collins 2017; Vaillancourt et al. 2012, viii). Created immediately after the repeal, the song reappraises the past while taking the present and possibilities for the future into account.

1 All translations in this article are my own. 
(2) Bon Cop Bad Cop (2006) is a bilingual English-French film directed by Eric Canuel, who was born in the only officially Francophone province, Quebec, where French is the majority language. It is the province with the highest percentage of bilingual speakers: $34 \%$ of French and $62 \%$ of English native speakers are bilingual (Henripin 2014). Quebec has a long history of antagonism between English and French, and the relationship between the two languages "remains a contentious issue" (Stern, Leblanc, and Laurendeau 2016), which is reflected in the film. Bon Cop Bad Cop is about a transborder murder (the victim is found on top of the border sign between Ontario and Quebec) which has to be solved by detectives from each province working together. The film illustrates different variations of dealing with bilingualism in Canadian society.

(3) À Moncton is a song by Marie-Jo Thério (2005), a Canadian singer from Moncton, New Brunswick, the only officially bilingual city in the only officially bilingual province of Canada. The song is in Chiac, a mixed language based on English and French that is spoken in the area. It is about a young woman calling her friend on the telephone on a Saturday night in the city of Moncton.

The three works reflect the complex history of, and linguistic and cultural relations in, each province. They comprise various settings and possible models for a bilingual community, ranging from parallel language communities in 1916, to translanguaging in a bilingual setting in Bon Cop Bad Cop, to a mixed-language setting in À Moncton.

\subsection{6}

The song 1916 (Jean 1986) is set at a time in Manitoban history when the Francophonie was in danger of disappearing. In 1916, the right to teach in French was abolished in Manitoba, establishing English as the "only authorized language of instruction” (Manitoba Government "Policy for Heritage Language Instruction”). The song is structured as an argument between an Anglophone official enforcing the law, represented by tenor and bass singing in English, and a Francophone teacher who would like to continue teaching in French, represented by soprano and alto singing in French. The English "inspecteur" has written a letter to the teacher, telling her to stop teaching in French, arguing that French is destined to die. The teacher is considering the request and formulating her response. Even though there is no code-switching by either of the two interlocutors, there is a constant switch between the languages from one interlocutor to the other. Language choice plays an essential role in constructing identities in 1916, as it is the easiest and most obvious way of showing who is representative of which community, establishing cultural affiliations at first glance. Even though the historical context 
of the abolition of the bilingual education system seems to indicate a linguistic imbalance, the de facto distribution of language use as well as the strong resistance of the French interlocutor on a content level are both indicative of the context in which the song was written: the year after the repeal of the abolition decree, when French minority language rights were re-established. The song shows an even distribution of English and French; both parties are allocated comparable shares of the conversation, and interact on equal terms and with equal rights.

At first, both parties let each other finish speaking before answering (measures 9-27), then they start singing in alternating, overlapping phrases, getting shorter towards the end (measures 29-47, 49-53, 70-81, 86-89, 94), interrupted by short passages where they sing simultaneously (measures 47-48, 54-66, 82-83, $90,96)$, almost shouting over each other. The two voices harmonize on a musical level, even though they are in opposition to each other with regard to content. The overlaps and interruptions often render the actual text incomprehensible to the listener. The two languages seem to compete for attention, each trying to gain the upper hand, yet who is heard in the end remains open. There is no clear resolution on the content level, as the song ends with "time will tell”/“on verra” [we'll see], postponing a potential solution to the unspecified future, whereas on the musical level there seems to be a harmonious agreement.

1916 portrays Francophone and Anglophone identities as equal, if conflicting forces, separate and independent of each other on one level, while at the same time harmonizing and intertwined on a different level. However, Jean does not present an unambiguous solution to the existing conflict between the two languages, which he leaves to the listener's imagination. The song aptly reflects the historical situation of the province, both through the depiction of linguistic discrimination against Franco-Manitobans, which still remains in the collective memory as a traumatic experience (Blay 1987, n. pag.), and through resistance against such linguistic injustice. As the song was created one year after the repeal of the 1916 decree, it ends on a more hopeful note, providing a renewed basis for a harmonious and more equal bilingual community in the future.

\subsection{Bon Cop Bad Cop}

The bilingual English-French film Bon Cop Bad Cop (dir. Canuel 2006) illustrates another example of how language use and identity are interconnected. The film is set in Ontario and Quebec, and tells the story of two detectives, the Anglophone Martin Ward from Ontario and the Francophone David Bouchard from Quebec, who are forced to work together to solve the murder of a victim who has been found on the border sign between Ontario and Quebec and who is only the first 
in a series of victims that are killed in both provinces. The two - at first - reluctant partners seem to serve as metaphorical representations of Anglophone and Francophone Canada. The development of their relationship from antagonism to cooperative synergy, as well as their language choice and use of code-switching and translanguaging in the process, can be interpreted as an example of the successful construction of a joint Canadian identity. The film depicts several realizations of bilingual interaction, which can be interpreted as different stages on a scale, ending in a symbiotic use of and a successful collaboration between both languages.

David Bouchard uses his Québécois French to exclude unwelcome (Anglophone) interlocutors and to disassociate himself from others. At the beginning of the film, he excludes Martin Ward by speaking a very fast Québécois French, using a Québécois accent and expressions to assert his identity in opposition to the Anglophone Ward. Through these means he creates a specifically Franco-Québécois identity in opposition both to Anglophone identities and to the French spoken in France (Martin Ward actually speaks Parisian French but has difficulties with Québécois slang). At the beginning of the film, even though David Bouchard uses formulaic phrases such as "Ça m’a fait plaisir" [my pleasure] (0:10:23-0:10:24) when speaking to Martin Ward, he makes use of English to convey his actual message, construing Anglophone identity as ignorant of French, as in the aside to his Francophone colleagues in the following example:

\footnotetext{
Martin Ward: "As you can see, the subject was a true Quebecer ... his heart is in Quebec.”

David Bouchard: “Ouais. Et il a l'Ontario dans le cul aussi.” [And he’s got Ontario up his ass, too.]

Martin Ward: "Excuse me?"

David Bouchard: “I just said his ass belongs to you.” (0:12:18-0:12:37)
}

David Bouchard also falls back on using French when he is verbally attacked on the level of his identity as a Francophone policeman during an English-language interview later in the film (1:03:30-1:03:51). Using French to exclude and insult the interviewer, he re-establishes his own superiority and Francophone identity. In these cases, Francophone identity is created in opposition to the supposedly monolingual Anglo-Canadian majority identity.

While they are both still very reluctant to work with each other, they agree on dealing with the bilingual context by implementing a clear geographical language separation. David Bouchard insists on a French-only policy when working in Quebec, and even though Martin Ward suggests making the language of interrogations dependent on the native language of those questioned, they finally agree on using French in Quebec and English in the rest of Canada "with the possible exception of some areas in New Brunswick" (0:23:22-0:23:43). David Bouchard 
even goes so far as to refuse to help Martin Ward in a bar fight until he asks for help in French (0:29:56-0:30:18), although the latter pays him back in kind later in the scene (0:31:15-0:31:41). This form of language distribution based purely on geography serves humorous purposes in the film and is represented as an option that does not fulfil the intended interactional purpose. It is presented as a very rigid and formal distribution of Canadian identities, relying on external factors and completely ignoring any (inter)personal considerations.

In one scene of the film, a translation approach is taken by David Bouchard's superior. He provides direct translations into both languages (0:14:11-0:15:11). However, this approach is also slightly ridiculed, both because his translations are heavily accented and somewhat flawed, and because the two people he addresses, David Bouchard and Martin Ward, both understand English and French, meaning that a translation is superfluous. This depiction suggests that an official translation policy does not necessarily solve the problem of a bilingual community and does not support cooperation either, making it in fact quite the opposite: time-consuming, inaccurate, and ineffective.

Martin Ward often uses French to create rapport: he uses "language to promote [or] maintain [...] harmonious social relations” (Spencer-Oatey 2004, 3). He shows his ability and willingness to accommodate to a Francophone environment. Examples of this are his use of "enchanté" [nice to meet you] when meeting his Francophone partner for the first time (0:10:56) or when he consciously switches to French when speaking to the Francophone medical examiner: "Why is there blood - p-pourquoi il y a du sang?” (0:19:52-0:19:54). He uses language to improve interpersonal relations, which requires both a degree of linguistic self-confidence and a willingness to accept and adapt to others' linguistic identities. It is not surprising that the Anglophone main character should be depicted as using this approach, for it is easier to achieve this degree of linguistic confidence if the image of one's own native language in society is not collectively perceived as endangered by a minority situation and a history of suppression.

Finally, once the two main characters have established that they are both capable of understanding and speaking both languages, they start mixing English and French in their utterances, as Martin Ward does in the following example:

David Bouchard: “Tu parles français, toi? ” [You speak French?]

Martin Ward: "Non, je parle pas français, je me suis fait installer un petit gadget au cerveau and I see subtitles under people when they speak. Oui je parle français."

[No, I don't speak French, I've had a little gadget installed in my brain and I see subtitles under people when they speak. Yes, I speak French.] (0:15:36-0:15:45) 
The two main characters also start using English and French when talking to each other, each using the language he feels most comfortable with, accepting that the other will understand him. When they speak the other's language, they sometimes have slight difficulties with words and pronunciation, which keeps language use realistic. In such cases, they move to a metalinguistic level, talking about language use and helping each other with translations and expressions. For example, David Bouchard teaches Martin Ward about Québécois insults such as tabarnak and how to use them (0:31:43-0:33:50), whereas when David Bouchard tries to transfer the French habitudes directly into English and ends up with "habituds-isms" during an English-language interview, Martin Ward intervenes and supplies the word "habits" (1:03:15-1:03:19).

They thus create a true partnership where both languages are equally acceptable and are used almost interchangeably. This could be interpreted as a case of "language alternation itself as the medium," which Gafaranga and Torras (2002, 11-12) define as a conversation in which "two languages are used, [but] participants do not take any notice of the difference between the two. In other words, they do not orient to the two languages as two distinct realities." This is also typical of translanguaging, which "considers the language practices of bilinguals not as two autonomous language systems [...] but as one linguistic repertoire" (García and Wei 2014, 2), creating a new bilingual reality and, by extension, identity.

Although several possibilities for dealing with bilingual contexts are portrayed in Bon Cop Bad Cop, it becomes clear that the creation of a joint bilingual Canadian identity, where both Francophone and Anglophone identities accommodate and understand each other, provides the highest potential for success, conceding equal language rights to both parties and reconciling both linguistic identities. The two protagonists succeed in effectively working together, profiting from the synergy of their combined strengths to save the all-Canadian sport of ice hockey.

\section{3 À Moncton}

A potential further step in identity construction is illustrated by the emergence of a hybrid identity in our last example, À Moncton by Marie-Jo Thério (2005). Since New Brunswick is the only province of Canada that is officially bilingual, and Moncton, which lies in the bicultural south-east of New Brunswick, is the only officially bilingual city of Canada (Boudreau and Perrot 2005, 8), it is not surprising that a contact language between English and French should originate there. Moncton is characterized by a Francophone language continuum which reaches 
from the standardized French taught in the educational system; to traditional Acadian French (i.e. the Canadian French spoken mostly in New Brunswick, in Nova Scotia, and on Prince Edward Island; see Smith 2011, 312); to the mixed language Chiac, which integrates English lexis, morphology, and syntax into Acadian French (Boudreau and Dubois 2001, 38). Auer (2014, 322) observes that "arguably, this variety has an aspect of playful distortion of French to it, a partly conscious, identity-related effort to create something very specific.” Chiac has long been stigmatized as a non-standard minority variety, but speakers of this mixed language keep fighting for a broader acceptance of Chiac identity as a possibility for unifying several linguistic dimensions (Boudreau and Dubois 2001, 49-50).

In her song À Moncton, Marie-Jo Thério sings about a young woman who calls her friend Gisèle because she is bored and there is nothing to do on a Saturday night in Moncton. She asks her friend about her plans for the summer and tells her about her own life. There are some deviations from standard French. The masculine gender of job, for example, changes to feminine "une job.” There are also slight variations in conjugation, for example "j”vas fitter" [I will fit] instead of je vais, using the second- instead of the first-person singular of the future proche, or "penser aux années qui s'en v'nont"2 [think of the years that are to come] with "v'nont" instead of viennent in the third-person plural, which are typical features of Acadian French (see also Smith 2011, 312, 317).

Many English terms and expressions are directly introduced into French without further adaptation, for example "weird," "boring," "I guess," and "at least.” Some are also combined with articles, personal pronouns, or direct objects without being altered, such as "un boyfriend," "je start," "watch-moi," or "I hope je te bother pas" (using the French negation with an unchanged English verb). Other instances mix the languages further, for example by adapting English words to French syntax and morphology: for instance, (to) call is conjugated as "j'te callais” (imparfait), or (to) coax as “j’ai coaxé Mike” (passé composé), although the meaning in the latter is also slightly changed since English I've coaxed Mike implies that he has been convinced, whereas here Mike refuses. The French infinitive suffix -er is also sometimes added to English infinitives, thus "Frenchifying" the Anglicism (e.g. "watcher” and “fitter").

The song also includes mixed phrases that integrate both languages. In the example "une job full-time," the English expression full-time job is adapted to French syntax with the adjective following the noun. French is also adapted to English syntax, as in "y a rien qui va on" [there is nothing going on], using (mostly)

2 The transcription of the song that serves as basis for the analysis was corrected orthographically in this instance. 
French words to express an English idiom. The expression “j’serai déjà long gone” [I will already be long gone] seems to be a mix of a French beginning and an English end, with language choice apparently inconsequential for conveying the message.

There are also some new creations which are easily comprehensible but cannot be clearly attributed to either language. "J'aurai pris la go" clearly means "I will have left"; however, there does not seem to be either an English or a French origin to this expression, making it a new mixed form that is inherently Chiac. Likewise, the meaning of "stallée" in "ben stallée dans des pensées" [remaining in the thoughts] is easily comprehensible, yet its origin is not quite clear. It could be a figurative use of a shortened version of the French bien installée "feeling at home," or it might be derived from the English (to) stall, the latter being employed in a figurative way, not in the sense of being delayed but rather meaning "remaining."

This playful way of dealing with a bilingual context in $\grave{A}$ Moncton seems to indicate a Francophone identity that does not feel threatened and is not in "competition" with Anglophone identity. Rather, it could be interpreted as an appropriation of English by Franco-Canadian speakers, leading to a peaceful coexistence in which the two parts complement each other. Thus, Chiac could be seen as a new and separate hybrid identity, without the prejudice that is often inherent in the interactions between the French and English "standards" it is derived from.

\section{Language choice and the construction of Canadian identities}

The three examples of contemporary Canadian popular culture analysed above 1916, Bon Cop Bad Cop, and À Moncton - demonstrate three different views of the relationship between English and French and the interplay between identities in the Canadian bilingual context, ranging from a parallel depiction of identities that are recognized as autonomous yet inextricably interconnected parts of a whole; to an equal partnership where language does not divide but unites to create a joint bilingual identity; to a mixed and hybrid identity. The examples illustrate an assumption of shared linguistic comprehension in the audience that is made possible only by the status of Canada as an officially bilingual country, reinforced by additional constitutional support in the three provinces in question. Even though the actual distribution of bilingual speakers is far from ideal in the Canadian context, the national narrative of Canada as a bilingual country gives agency to individuals to create a common national identity through bilingual practices despite the differing and opposing realities in the various provinces. The linguistic choices in the analysed works thus present variations of an imagined national 
identity based on bilingualism, while at the same time critically engaging with the particular linguistic contexts in each of the provinces concerned: the setting of a protected minority with a strong history of discrimination; a complex and often antagonistic interaction between English and French in a French majority situation; and a fully bilingual context that permits hybridization. This is also reflected in the degree of interconnection between the two languages in the three examples, which ranges from separate and parallel, yet interacting and intertwined use; to a synergetic translanguaging approach in a bilingual context; to a mixing of languages on all levels, creating a new language where linguistic origins are no longer fully separable. The bilingual national narrative thus furthers the creation of shared national identities despite linguacultural oppositions on provincial and individual levels. The three works of popular culture illustrate how the challenges of an officially bilingual country can be met with regard to society at large, as well as on an individual level in interpersonal interactions. This could even be extended to address the challenges posed by the multicultural and multilingual mix of identities in the Canadian mosaic.

\section{Works cited}

Anderson, Benedict. Imagined Communities: Reflections on the Origin and Spread of Nationalism. London: New Left Books, 1983.

Auer, Peter. "A Postscript: Code-Switching and Social Identity." Journal of Pragmatics 37.3 (2005): 403-410.

Auer, Peter. "Language Mixing and Language Fusion: When Bilingual Talk Becomes Monolingual.” Congruence in Contact-Induced Language Change: Language Families, Typological Resemblance, and Perceived Similarity. Ed. Juliane Besters-Dilger, Cynthia Dermarkar, Stefan Pfänder, and Achim Rabus. Berlin and Boston: De Gruyter, 2014. 294-335.

Auer, Peter, and Carol M. Eastman. “Code-Switching.” Society and Language Use. Ed. Jürgen Jaspers, Jan-Ola Östman, and Jef Verschueren. Amsterdam and Philadelphia: John Benjamins, 2010. Vol. 7 of Handbook of Pragmatics. 84-112.

Baker, Will. Culture and Identity through English as a Lingua Franca: Rethinking Concepts and Goals in Intercultural Communication. Berlin: De Gruyter, 2015. Developments in English as a Lingua Franca 8.

Bakker, Peter, and Yaron Matras. "Introduction." Contact Languages: A Comprehensive Guide. Ed. Bakker and Matras. Berlin and Boston: De Gruyter, 2013. 1-14.

Barker, Chris. Cultural Studies: Theory and Practice. London: Sage Publications, 2000. Barth, Fredrik. Ethnic Groups and Boundaries: The Social Organization of Culture Differences. Oslo: Universitetsforlaget, 1969.

Blay, Jacqueline. L’Article 23: Les Péripéties législatives et juridiques du fait français au Manitoba, 1870-1986. Saint-Boniface: Éditions du Blé, 1987. 
Boudreau, Annette, and Lise Dubois. “Langues minoritaires et espaces publics: Le Cas de l'Acadie du Nouveau-Brunswick.” Estudios de Sociolingüística 2.1 (2001): 37-60.

Boudreau, Annette, and Marie-Eve Perrot. "Quel Français enseigner en milieu minoritaire? Minorités et contact de langues: Le Cas de l'Acadie." GLOTTOPOL: Revue de sociolinguistique en ligne 6 (July 2005): 7-22. http://glottopol.univ-rouen.fr/numero_6.html (31 July 2018)

Boulianne, Guy, Norman Dugas, and Gérard Jean. “1916.” Ma plaine à moi: Hommage à Ziz. CD supplement. Polar Bear Productions, 2010.

Brunner, Marie-Louise, and Stefan Diemer. "'You are struggling forwards, and you don't know, and then you ... you do code-switching ...': Code-switching in ELF Skype conversations." Journal of English as a Lingua Franca 7.1 (2018): 59-88.

Canuel, Eric, dir. Good Cop Bad Cop: Erst schießen dann fragen. 2006. Alamode Film, 2007. DVD.

Cashman, Holly R. “Identities at Play: Language Preference and Group Membership in Bilingual Talk in Interaction." Journal of Pragmatics 37.3 (2005): 301-315.

Collins, Emmet. "Francophones of Manitoba." The Canadian Encyclopedia. Ed. James H. Marsh. 2017. https://www.thecanadianencyclopedia.ca/en/article/francophones-of-manitoba (31 July 2018).

Edwards, John. Language and Identity. Cambridge: Cambridge University Press, 2009.

Gafaranga, Joseph, and Maria-Carme Torras. "Interactional Otherness: Towards a Redefinition of Codeswitching." International Journal of Bilingualism 6.1 (2002): 1-22.

García, Ofelia. Bilingual Education in the Twenty-First Century. Oxford: Wiley-Blackwell, 2009.

García, Ofelia, and Li Wei. Translanguaging: Language, Bilingualism and Education. Basingstoke and New York: Palgrave Macmillan, 2014.

Hall, Stuart. "The Question of Cultural Identity." Modernity and its Futures. Ed. Hall, David Held, and Anthony G. McGrew. Oxford: Polity Press, 1992. 274-316.

Henripin, Jacques. "Languages in Use.” The Canadian Encyclopedia. Ed. James H. Marsh. 2014. https://www.thecanadianencyclopedia.ca/en/article/languages-in-use (31 July 2018).

Jean, Gérard. “1916.” L’Article 23/Section 23. Prod. David Arnason, Claude Dorge, and Gérard Jean. Co-prod. Cercle Molière. n.p. : Prairie Theatre Exchange, 1986. Sheet music.

Manitoba Government. "Policy for Heritage Language Instruction." Education and Training. Manitoba Government, n.d. http://www.edu.gov.mb.ca/k12/docs/policy/heritage (10 June 2014).

Ochs, Elinor. “Constructing Social Identity: A Language Socialization Perspective.” Research on Language and Social Interaction 26.3 (1993): 287-306.

Office of the Commissioner of Official Languages, Barbara J. Burnaby. "Language Policy.” The Canadian Encyclopedia. Ed. James H. Marsh. 2015. https://www.thecanadianencyclopedia. ca/en/article/language-policy (31 July 2018).

Smith, John Charles. "Variable Analyses of Verbal Inflection in (Mainly) Canadian French." Morphological Autonomy: Perspectives from Romance Inflectional Morphology. Ed. Martin Maiden, Smith, Marie Goldbach, and Adam Ledgeway. Oxford: Oxford University Press, 2011. 311-326.

Spencer-Oatey, Helen. “Introduction: Language, Culture and Rapport Management.” Culturally Speaking: Managing Rapport through Talk across Cultures. Ed. Spencer-Oatey. London: Continuum, 2004. 1-8. 
Stern, Hans Heinrich, Raymond A. Leblanc, and Paul Laurendeau. "Second Language Instruction.” The Canadian Encyclopedia. Ed. James H. Marsh. 2016. https://www.the canadianencyclopedia.ca/en/article/second-language-instruction (31 July 2018).

Swann, William, and Jennifer Bosson. "Identity Negotiation: A Theory of Self and Social Interaction." Handbook of Personality: Theory and Research. Ed. Oliver P. John, Richard W. Robins, and Lawrence Pervin. 3rd ed. New York: Guilford Press, 2008. 448-471.

Thério, Marie-Jo. À Moncton. 2005. Transcribed by user joualvertLA. YouTube. 2008. https:// www.youtube.com/watch?v=jxev9qgQnlg (31 August 2017).

Vaillancourt, François, Olivier Coche, Marc Antoine Cadieux, and Jamie Lee Ronson. Studies in Language Policy: Official Language Policies of the Canadian Provinces: Costs and Benefits in 2006. n.p.: Fraser Institute, 2012.

Wolf, Werner. The Musicalization of Fiction: A Study in the Theory and History of Intermediality. Amsterdam: Rodopi, 1999. Internationale Forschungen zur Allgemeinen und Vergleichenden Literaturwissenschaft 35.

Marie-Louise Brunner is head of the intercultural communication program and director of the Institute for International and Digital Communication (InDi) at Trier University of Applied Sciences, Germany. She is currently working on her $\mathrm{PhD}$, which analyses meaning and identity negotiation in English as a lingua franca communication via Skype. Her research interests include discourse analysis and intercultural communication. 